\title{
A PROFILE OF ADOLESCENTS IN HOUSEHOLDS INFECTED WITH, OR AFFECTED BY, HIV AND AIDS
}

\section{Korita Olivier and Herman Strydom}

\section{INTRODUCTION}

This article will focus on a profile of adolescents' households infected with, or affected by, HIV and AIDS. A comprehensive needs assessment by way of a structured schedule was completed by means of in-depth interviewing. Interviews were conducted with 169 households in two provinces of South Africa and included two black ethnic groups and a coloured group. To draw up the profile issues such as demographic data, number of members of households, main caregiver, child-headed household, school attendance, health and wellbeing, employment, receiving of grants, total household income, death of parents and family members, and bereavement counselling were covered.

\section{PROBLEM STATEMENT}

According to the UNAIDS "Global summary of the AIDS epidemic" (2006), there were an estimated 39.5 (34.1 to 47.1) million adults and children infected with HIV worldwide by the end of 2006. Of this total, 24.7 (21.8 to 27.7) million are from Sub-Saharan Africa, of which 4.5 to 6.3 million are from South Africa. Abdool Karim, Abdool Karim and Baxter (2005:37) point out that it is estimated that a further 1700 people in South Africa to become infected with this virus daily. HIV/AIDS is by far the largest, most pervasive and tragic current health crisis in South Africa (Podile, 2004:1; Strydom, 2003:59) and, according to Visser (2005:204), it has reached pandemic proportions. Roalkvam $(2005: 218)$ states that AIDS illnesses primarily kill the mid-generations and isolate the children.

Currently, in South Africa, it increasingly happens that parents become terminally ill with AIDS. Gow and Desmond (2002:63) estimate that by 2015 children (including adolescents) orphaned by AIDS will constitute between 9\% and 12\% of South Africa's total population. Adolescents in this situation are confronted with special circumstances, such as living without parental support and protection, having to care for ill parents and family members, and being deprived of nutrition, health care and shelter (Kaseke \& Gumbo, 2001:54; Valdiserri, 2003:182).

These adolescents are left emotionally and psychologically vulnerable when they experience the illness and death of their parents as result of AIDS (Mynhardt, 2002:10). The quality and availability of health, welfare and education systems are deteriorating because of demands created by this epidemic (Richter, Manegold \& Pather, 2004:5). Responses to adolescents affected by HIV and AIDS should address their basic needs (Ungar, 2005:256), which is precisely the reason for doing a needs assessment. The eventual aim of this study is to develop, present and evaluate an empowerment programme for adolescents in this situation.

\section{OBJECTIVE}

The objective of this article is to explore the circumstances, and compile a profile, of adolescents in households where parents/caregivers are infected with, or affected by, HIV and AIDS. 


\section{TERMINOLOGY}

\section{HIV AND AIDS}

According to Becker (2005:103) and Gifford, Lorig, Laurent and Gonzalez (2000:5), HIV refers to the Human Immunodeficiency Virus, which is the virus that causes AIDS by destroying important cells which control and support the immune system. AIDS is the acronym for Acquired Immunodeficiency Syndrome, which is the collective name for the complications that follow when a damaged immune system cannot fight infections (Barnett \& Whiteside, 2002:28; Herbst, 2002:18; Van der Westhuizen, 2006:14). Buthelezi (2003:19) stresses that people do not die of AIDS, but of opportunistic diseases and infections which attack the body when immunity is low.

\section{ADOLESCENCE}

Barker (2003:8), Scholtz (1998:16) and Strydom (2003:61) state that "adolescence" normally refers to the life-cycle period between childhood and adulthood, beginning at puberty and ending in adulthood. Harrison (in Abdool Karim et al., 2005:263) defines adolescence as a specific developmental stage that spans the period from puberty into young adulthood and which is characterised by transition, physical and emotional development, and change. The participants in this study were between 13 and 17 years of age.

\section{HOUSEHOLD}

Household refers to all people, whether or not related, who live in the same dwelling unit (Barker, 2003:201). This includes individuals as well as groups of people.

\section{RESEARCH METHODOLOGY}

Intervention research, according to the Design and Development (D\&D) model, consisting of six phases, was utilised for this study (De Vos in De Vos et al., 2005:392-407). Only the first two phases of the D\&D model were covered during this part of the study: they are problem analysis and project planning, and information gathering and synthesis. An interview schedule with face-to-face interviewing was chosen as data-collecting procedure to gain maximum structuring of the process, to motivate participants to participate, and to gain optimal communication between researcher and interviewee (Alasuutari, Bickman \& Brannan, 2009:317). Data were gathered in a non-probability sampling fashion, and specifically the accidental sample, seeing that the population size was not known to researchers (Neuman, 2006:220; Strydom, 2005a in De Vos et al., 2005:201-202). In this manner a total number of 169 households were interviewed by volunteer fieldworkers from local hospices.

Before this study was conducted, permission was obtained from the Ethics Committee of the North West University. Participation in this study was strictly voluntary and informed consent was obtained from the participants after all the aspects of this particular research project had been explained to them (Strydom, 2005b in De Vos et al., 2005:59). Anonymity, confidentiality and respect for participants' rights were also taken into consideration (Harrison \& Wise, 2005:20; Kartell \& Chabilall, 2005:215; Monette, Sullivan \& Dejong, 2008:55-57). The findings of the study should not have a negative impact on the participants and they should be protected from unwarranted physical or mental discomfort, distress, harm, danger or deprivation (Strydom, 2005b in De Vos et al., 2005:67). The data of this study were statistically computed with SAS (SAS Institute Inc, 2003). The results were interpreted, inferences were made and conclusions drawn. 


\section{RESULTS}

The results will be discussed under specific headings, such as who the main caregiver of the household is, whether it is a child-headed household per definition, school attendance of the adolescents, the degree of health and wellbeing in these households, employment-related issues, death of parents and family members, and bereavement counselling and support to these households with a specific focus on the adolescents in them.

\section{DEMOGRAPHIC DATA}

The study was carried out in the Eastern Cape Province and the North West Province of South Africa, comprising Xhosa, Tswana and coloured people. A total of 169 households from Tokyo Sexwale and Pellsrus communities in Jeffreys Bay (Eastern Cape Province) and Ikageng and Promosa communities in Potchefstroom (Tlokwe) (North West Province) participated in the study. The majority of respondents, namely 89 (52.66\%), were isiXhosa speaking, while 40 $(23.67 \%)$ were Setswana and $40(23.67 \%)$ Afrikaans.

\section{MEMBERS OF HOUSEHOLD}

This topic will be discussed according to the following categories of household members.

- Baby/preschool/crèche attending children in the household

The majority of households (66.27\%) did not have a baby or a preschool/crèche-attending child as part of the household. A total of $33.73 \%$ of households have at least one or more babies or preschool/crèche-attending child.

- Scholar/student present in the household

The majority, namely 122 (72.19\%) households, have one or two scholars or students (schoolattending children) in their household. It was found that $41(23.63 \%)$ of households have children that are of school-going age, but who are not attending school.

- Retired and disabled individuals present in the household

In $36(21.30 \%)$ households there are one or two retired members. Only nine $(5.33 \%)$ households have members who are living with disabilities. Of these, three $(1.78 \%)$ households indicated having a disabled person(s) with casual work as part of their household. Of the total number of households, six $(3.55 \%)$ indicated having a person who is disabled without casual work as part of their household.

- Male and female

A question was asked to determine how many male and female members there were in the households. An overall $11.24 \%$ of the respondents indicated that they have four or more male persons per household and $17.16 \%$ of respondents indicated four or more female persons forming part of their household. Of all the respondents, $41.42 \%$ of households indicated having no male adult as part of their household. Only $3.55 \%$ of households indicated having no female adult as part of their household. In $40.83 \%$ of households there was only one male adult in their household. In $66.86 \%$ of households there was one female adult as part of their household. From these findings it can be deduced that a large number of these households have no male adult living permanently in the family, which can create difficulties in disciplining children, especially the boys, in these households. Financial problems prevail because of the absence of the head of the household, with often only one person, the mother, earning an income. Her absence during the day in turn creates other serious psycho-social problems in the household. 
If the attention turns to male and female children specifically, it can be seen that the majority of households $(\mathrm{N}=169)$ have one or two male or female children as part of their household. In $24.85 \%$ of households they do not have any male children in their household and $31.36 \%$ of households do not have any female children as part of their household. In $7.7 \%$ of households they have three or more male children per household and $12.43 \%$ of households have three or more female children per household. It was found that $51.23 \%$ of male children and $55.49 \%$ of female children were between the ages of 12 and 18 years. Therefore the majority of children (male and female) in this study are in the adolescent stage and it is therefore evident why the focus of this study is on adolescents.

- Family members and non-family members

A question was posed to determine how many of the household members were family members and how many were non-family members. The research reveals that only $6.72 \%$ of respondents from the Eastern Cape indicated having three male family members as part of their household, compared to $34 \%$ of respondents from North West who indicated having three male family members in their household. These households do not have many, if any, male members in their household who are not family. In the Eastern Cape $38.66 \%$ of households indicated having two female family members in their household and only $8.88 \%$ of respondents in North West have two female family members as part of their household. From the data above it is clear that the households $(\mathrm{N}=169)$ consist mostly of family members. Only two households indicated having non-family members as part of their households.

If the aforementioned categories are taken into consideration, it can be concluded that the majority of these households experience a serious problem with overcrowding. According to Van der Westhuizen (2006:19), crowded living conditions have the disadvantage of causing a negative lifestyle and many other psycho-social problems.

\section{MAIN CAREGIVER}

The responses to a question asked to determine who the main caregiver of the household is were as follows: in $95(56.21 \%)$ households the mother or the father or both were the main caregivers although, on average, the head of the household is the mother $(36.90 \%)$. Studies done by Kamali, Seeley, Nunn, Kengeya-Kayondo, Ruberantwari and Mulder (in Bor, 1998:225) indicated that loss of the father was more common than that of the mother. A total of $42.27 \%$ of the main caregivers in households were family members (other than parents) such as a brother or sister, grandparents or other relatives. In only $1.19 \%$ of households was the main caregiver not a relative, but a friend or neighbour.

\section{CHILD-HEADED HOUSEHOLD}

In answer to a question attempting to determine whether the parents in these households were still alive, only $32(18.94 \%)$ households indicated that both the parents of the children in that household were still alive, while in 106 (62.72\%) households children have only one parent still alive and in 31 (18.34\%) households both parents of the children had already passed away. Of this large number of one-parent households, $35(33.02 \%)$ indicated that the mother of the children in the household had passed away and $71(66.98 \%)$ indicated that the father of the children in the household had passed away.

For the purposes of this study a child-headed household implies that the person heading the household and caring for younger siblings is under the age of 18 years when orphaned, mostly by AIDS (Kartell \& Chabilall, 2005:214), with no adults forming part of the household. These 
adolescents experience a heavy responsibility in facing the challenge of taking care of and supporting younger siblings (Van der Westhuizen, 2006:24).

Although in 31 (18.34\%) households in this study both parents had already died, it was found that only four $(2.37 \%)$ households $(\mathrm{N}=169)$ in this study were child-headed per definition. This can be attributed to other adult members of the family stepping in to care for these children. Roalkvam (2005:211) states that the most obvious characteristic of the child-headed household is its isolation. These households appear to be invisible to the community surrounding them, which could be the reason why so few of these households were included in this research.

\section{SCHOOL ATTENDANCE}

A total of $122(72.19 \%)$ children in households involved in this study of school-going age are attending school. Of the children attending school, $90.54 \%$ of them are attending 16 days or more per month. Of the 45 (26.63\%) households with children not attending school, 29 $(64.45 \%)$ households in this study have one child of school-going age not attending school, while $15(33.33 \%)$ households have two children of school-going age not attending school, and one $(2.22 \%)$ household indicated having three children of school-going age not attending school.

The most common reasons proffered for children of school-going age not attending school were the following: $14(31.11 \%)$ responded that they could not afford school fees; $11(24.44 \%)$ indicated that they had dropped out of school for personal reasons; and six $(13.33 \%)$ indicated that they have to take care of either an ill family member or younger siblings. The need to take care of ill family members is typical of the AIDS pandemic. Ghosh and Kalipeni (in Kalipeni 2004:311) confirm this by stating that adolescents are more likely to drop out of school as a result of financial difficulties, illness or the social stigma attached to parents dying of AIDS. It was also determined that the average progress of children attending school included in this study, according to school reports, can be described as average to good.

\section{HEALTH AND WELLBEING}

In answering a question probing whether household members were tested for HIV and whether any members were infected with HIV, more than two-thirds, namely $116(68.64 \%)$ households, indicated that they (or some members of the household) were tested for HIV infection. Almost a third, namely $53(31.36 \%)$, of households indicated they had never before been tested for HIV infection, which is alarming, taking the background of the HIV and AIDS pandemic into account. In the Eastern Cape $73.96 \%$ of households indicated that a member(s) had been tested for HIV, compared to $56 \%$ of households from North West who indicated a member(s) had been tested for HIV infection. This difference may again indicate that communities from the Eastern Cape are more open with regard to HIV and AIDS than the communities from North West.

People from communities in South Africa who are most vulnerable to HIV infection are children (including adolescents), young adults, women and the poor (Becker, 2005:105). Roux (2002:73) and Whiteside and Sunter (2000:32) point out that people between ages 15 and 45 years are most affected by HIV. Living in times such as these, when effective antiretroviral therapies are available to enable people infected with HIV to live longer, it is of the utmost importance to know one's HIV status.

Almost half of the households, namely 80 (47.34\%), that formed part of this research indicated that a member (or more than one) of their household was infected with HIV. This question was 
mostly answered reluctantly and can be an indication that the respondents were not totally honest about their status or that they are still not open to sharing information regarding their status.

A question was posed to determine whether any members of the household were terminally ill. It was indicated that only a few households have a terminally ill person. With regards to the highest rate of terminally ill persons in households, terminally ill mothers were the largest group. If one takes into consideration that mothers were the main caregivers in more than a third of the households, this can have a severe impact on the functioning of the household as well as on other members of the family, including adolescents.

\section{EMPLOYMENT}

The following responses were given as far as employment was concerned.

\section{- Head of household employed}

To a question on whether the head of the household was employed (part time or full time), the following responses were received. In 112 (66.27\%) households the head of the household was employed in some way or another. More or less a third of the households indicated having an unemployed head of their household, which could serve as an indication of the households' living standards (Van der Westhuizen, 2006:24).

\section{- Own housework}

The category implies that the person's main daily activity is housework in his/her own household or, in other words, the person is a "housewife". Only 12 (7.10\%) households have one person who was mainly a "housewife".

- Employed full time

Only $61(36.09 \%)$ households indicated that they have one or more people employed full time.

- Employed part time

In $81(47.93 \%)$ households one or more people indicated that they are employed part time.

- Self-employed

Only nine $(5.33 \%)$ households have one or two self-employed people as part of their household.

- Unemployed, seeking work

A total of $51(30.18 \%)$ households indicated having one or more persons in their household who are unemployed and seeking work.

- Unemployed, not seeking work

In $30(17.75 \%)$ households there were one or more persons who were unemployed and not seeking a job.

\section{- Disabled}

There were only a few persons - nine (5.33\%) - living with disabilities present in these households. Of these, only three $(33.33 \%)$ had casual work, while six $(66.67 \%)$ had no casual work.

It is an alarming fact that $57(33.73 \%)$ households in this study had a head who was not employed, which definitely has an influence on the household's living standard. Besides the heads of these households, only $61(36.09 \%)$ and $81(47.93 \%)$ households had one or more 
persons employed full time and part time, respectively. If the large number of the unemployed who are seeking work, namely 51 (30.18\%), and the 30 (17.75\%) not seeking work are taken into consideration, these figures paint a dark picture of the number of people who need to be sustained from one or two salaries only.

\section{GRANTS FROM GOVERNMENT}

A total of $105(62.13 \%)$ households in this study indicated receiving a grant(s) from the government. Of these households, $70(66.67 \%)$ receive a child-support grant and $35(33.33 \%)$ receive other grants, including HIV grants, disability or foster-care grant. The abovementioned 105 households receive 120 grants in total, which means that a household can receive more than one grant, for example, a foster-care grant as well as a disability grant. In the Eastern Cape $54.62 \%$ of households indicated that they receive a grant(s) from the government, compared to $80 \%$ of households responding from North West who receive a grant(s) from the government.

Actually it is a negative situation that so many households live off grants from government. The authors' view is that the government should initiate more job-creating projects, where people can work to earn a living with dignity. This statement naturally excludes people who are too ill, too old or too disabled to work.

\section{HOUSEHOLD INCOME}

In total $53(31.36 \%)$ households in this study have an average monthly income of R501.00 to 1000.00 . Only $12(7.10 \%)$ households have an average monthly income of less than R200.00, while only nine $(5.33 \%)$ have an average monthly income of more than R2 001.00. It is indicated that $134(79.29 \%)$ households have an average of one to three male household members and $138(81.66 \%)$ have an average of one to three female family members. Taking into account that the average household in this study consists of four to six persons, and that the average monthly income of most households is between R501.00 and R1 000.00, this could be an indication of the financial distress of these households. This definitely has an impact on family members' psycho-social functioning and wellbeing.

Two-thirds of the respondents indicated receiving grants from the government. Taking this into consideration with regard to the total monthly income of a household, it can be concluded that a large number of households depend on grants as their lifeline.

\section{DEATH OF PARENTS AND FAMILY MEMBERS}

Of the households in which a parent(s) had passed away, namely 137, only 51 (37.23\%) were informed of the anticipated or possible death of their parent(s). In $119(70.41 \%)$ cases where a parent(s) had passed away, children in these households were informed by a family member that their parent was going to die. A total number of $34(20.12 \%)$ were informed by the other parent and only $16(9.47 \%)$ of the parents themselves informed their children that they were going to die.

Of all households included in this study where children had lost a parent(s), 105 (76.64\%) were informed of the cause of death of their parent(s). Differences were found between the two provinces involved in the study and can perhaps be attributed to ethnic differences, as Niebuhr, Hughes and Pollard (in Bor, 1998:258) indicate in their study on children's knowledge of their parents' diagnoses. The lack of openness of respondents in the North West Province can also be seen as a reason for this difference.

The cause of death of the parent(s) in the studied households was mainly AIDS (69.81\%). Van der Westhuizen (2006:36) reported that in South Africa it was estimated that $40 \%$ of all adult 
deaths were a consequence of AIDS. Two other causes also indicated were TB (12.26\%) and pneumonia (14.15\%), which are both opportunistic diseases with respect to HIV. The majority of the respondents in North West $(57.89 \%)$ indicated pneumonia as the main cause of death of their parent(s), compared to only $4.6 \%$ of respondents in Eastern Cape. Pneumonia can be seen as an AIDS-related illness, but it cannot be implied that AIDS was the cause of death in these cases (Foster, Shakespeare, Chinemana, Jackson, Gregson, Marange \& Mashumba in Bor, 1998:212). This difference could also be yet another indication of the difference in openness regarding HIV and AIDS in households in Eastern Cape, on the one hand, and North West, on the other, where the researcher experienced the respondents from the Eastern Cape as being far more open about their circumstances than respondents from the North West Province.

A question was also posed regarding deaths in the families of the households during the past year. In 91 (53.85\%) households included in this study it was indicated that someone in the family (nuclear or extended) had passed away during the previous year. In $69(75.82 \%)$ cases the deaths were due to AIDS, which indicates that the respondents in this study (including adolescents) are severely affected by HIV and AIDS.

A total of 129 deaths in the family as a result of AIDS over time were reported. Roalkvam (2005:218) concludes that it is the mid-generations that are primarily killed by AIDS illnesses.

\section{BEREAVEMENT COUNSELLING AND SUPPORT}

Of the 137 households studied that had lost a parent(s), only 26 (18.98\%) indicated having received bereavement counselling after the death of their parent(s). Interestingly, 11.96\% of children in Eastern Cape indicated having received bereavement counselling after the death of their parent(s), compared to $42.31 \%$ of children in North West. The communities included in the research in the North West Province form part of Potchefstroom, a city with a network of resources and organisations rendering services in this field. The communities in the Eastern Cape included in this research form part of Jeffreys Bay, which does not even have one local organisation rendering social work services. The availability and accessibility of support services could possibly be the reason for this difference.

Of the 26 (18.98\%) children who lost a parent(s) and have received bereavement counselling after the death of their parent(s), $13(50.00 \%)$ received bereavement counselling from a pastor or minister and nine (34.62\%) from a neighbour. Bereavement counselling from a social worker was only indicated in four $(15.38 \%)$ cases. In $17(65.38 \%)$ cases where children had received other support after the death of their parent(s), the support was given by family members or neighbours. In only three $(11.54 \%)$ cases did the children receive other support from a social worker. It is regrettable that social workers were involved in only four (15.38\%) and three (11.54\%) cases regarding bereavement counselling and other forms of support respectively.

\section{DISCUSSION}

A comprehensive needs assessment by way of a structured schedule with in-depth interviewing was done to generate the findings reported on in this article. In order to draw up a profile, certain issues needed to be covered in the schedule. Some of these issues can be mentioned as the demographic information of adolescents in households, number of members of households, main caregiver, child-headed household, school attendance, health and wellbeing, employment, receiving of grants, total household income, death of parents and family members, and bereavement counselling. A total of 169 households from Tokyo Sexwale and Pellsrus communities in Jeffreys Bay (Eastern Cape Province) and Ikageng and Promosa communities 
in Potchefstroom (Tlokwe) (North West Province) participated in this study. The study indicated that most households consist mostly of family members, and adolescents formed part of most of these households. It was expected that more child-headed households would have formed part of this research, but the literature confirmed why such households are hidden from the community and difficult or almost impossible to reach with research. The households are characterised by terminal illnesses and deaths. Even at this advanced stage of the AIDS pandemic many of the respondents still indicated that no one in their family or household had ever been tested for HIV infection.

The results regarding infections and deaths as a result of AIDS differ considerably between the Eastern Cape and the North West Province. It has been confirmed throughout the study that the participants from the Eastern Cape were more open than those from the North West regarding matters pertaining to HIV and AIDS. Financial difficulties are a reality within most of the households, given their total monthly income. This indicates economic difficulties as being the strongest reason for children not attending school. In most of the families that responded in this research, only one of the two parents is still alive. Less than half of the children were informed of the anticipated death of their parent(s). In cases where the adolescent was informed of the cause of death, there was an unexpected openness regarding AIDS as cause of death of their parents. A serious lack of bereavement counselling was revealed and support after the death of a parent was minimal. The absence of social workers in these communities is especially worrying, seeing that social workers are trained in the issues of community work and HIV/AIDS. From the data collected in this research it became clear that adolescents in households infected with, or affected by, HIV and AIDS are confronted with various related problems and needs, as well as the specific needs related to adolescence as a stage of life. Hence it can be seen that on average the following can be said regarding a profile of adolescents in households infected, with or affected, by HIV and AIDS:

- Most households consist of non-family as well as family members;

- More than $40 \%$ of households do not have a male adult as part of their household;

- In more than a third of households the mother is the main caregiver;

- A terminally ill mother forms part of almost $10 \%$ of the households;

- A third of the households indicated that they have not yet been tested for HIV infection;

- Almost 50\% of the households tested for HIV infection have one or more HIV-positive household member(s), and more women than men tested positive;

- Two thirds of the household heads are employed;

- Almost two thirds of the households do receive grants from the government, of which $66 \%$ are child-support grants;

- More than half of the households receive less than R1 000.00 income per month per household;

- Almost $25 \%$ of households have one or more child of school-going age not attending school;

- In $90 \%$ of households where children are attending school, the school attendance is 16 or more days per month;

- The most commonly indicated reasons for not attending school include: could not afford school fees $(31 \%)$; dropped out of school $(24 \%)$; and have to take care of an ill family member (13\%); 
- More than $80 \%$ of children in these households indicated not having both parents still alive and almost $20 \%$ had already lost both parents;

- In more than $70 \%$ of instances the children were informed by a family member regarding the death of their parent;

- More than $75 \%$ of these children were informed of the cause of death of their parent(s) and in almost $70 \%$ of these cases the cause of death was AIDS related;

- Not even $20 \%$ of these children received bereavement counselling after the death of their parent(s) and in half of these cases the counselling was done by a pastor/minister or a neighbour. Social workers were almost non-existent in these communities.

\section{RECOMMENDATIONS}

It became clear that adolescents in households infected with, or affected by, HIV and AIDS have a unique profile. With a better picture of these adolescents' circumstances, any intervention with regard to adolescents in households infected with, or affected by, HIV and AIDS can be more specific and directed towards their unique needs. On the basis of the discussion of the results from this study as well as the conclusions drawn, the following recommendations can be made:

- This research can be extended and can be used as platform for the development of various interventions with adolescents in households infected with, or affected by, HIV and AIDS;

- Before any intervention or programme is planned for adolescents in these circumstances, a scientific needs assessment should be done within the given community to determine and verify that specific population's unique demographics;

- The circumstances in which adolescents have to grow into adulthood are difficult and as a group they should be a target population as far as help and support are concerned;

- A programme should be developed in response to the unique profile of adolescents in households infected with or affected by HIV and AIDS;

- An empowerment group work programme should be developed to help and support adolescents in circumstances such as these, especially with regard to the possible death of a parent/caretaker;

- The development of life skills for these adolescents, such as effective communication, assertiveness and conflict management, can be used as elements for an empowerment programme to help adolescents to be in a better position for their needs to be met;

- The profession of social work should take a serious look into its role in communities such as these, seeing that they generally have an important role to play at grassroots level in communities.

\section{CONCLUSION}

The purpose of this study was to explore the circumstances and compile a profile of adolescents in households where their parents/caregivers are infected with, or affected by, HIV and AIDS. The data collected serves as a starting point for developing and compiling a profile of these unique households. From the preliminary study it is obvious that this objective has been reached. To draw up a profile issues such as demographic data, number of members of households, main caregiver, child-headed household, school attendance, health and wellbeing, employment, receiving of grants, total household income, death of parents/family members, and bereavement counselling were covered. By exploring the circumstances of adolescents in 
households that are infected with, or affected by, HIV and AIDS it becomes obvious that adolescents have to face complex and unique circumstances with regard to the households in which they live. These challenges should be addressed by all the appropriate stakeholders in a coordinated manner.

\section{REFERENCES}

ABDOOL KARIM, S.S., ABDOOL KARIM, Q. \& BAXTER, C. 2005. Overview of the book. In: ABDOOL KARIM, S.S. (ed) HIV/AIDS in South Africa. Cape Town: Cambridge University Press: 31-36.

ALASUUTARI, P., BICKMAN, L. \& BRANNEN, J. 2009. The SAGE handbook of social research methods. London: Sage Publications.

BARKER, R.L. 2003. The social work dictionary. Washington: NASW Press.

BARNETT, T. \& WHITESIDE, A. 2002. AIDS in the twenty-first century: disease and globalization. Hampshire: Palgrave MacMillan.

BECKER, L. 2005. Working with groups. Cape Town: Oxford University Press Southern Africa.

BUTHELEZI, M.N.M.M. 2003. A social work study on the impact of HIV/AIDS in the South African Post Office in Durban. Pretoria: University of Pretoria. (MA(SW) Dissertation)

DE VOS, A.S. 2005. Intervention research. In: DE VOS, A.S. (ed) Research at grass roots: for the social sciences and human service professions. Pretoria: J.L. van Schaik Publishers: 392-407.

FOSTER, G., SHAKESPEARE, R., CHINEMANA, F., JACKSON, H., GREGSON, S., MARANGE, C. \& MASHUMBA, S. 1998. Orphan prevalence and extended family care in a peri-urban community in Zimbabwe. In: BOR, R. (ed) The family \& HIV today. London: Wellington House: 203-220.

GHOSH, J. \& KALIPENI, E. 2004. Rising tide of AIDS orphans in Southern Africa. In: KALIPENI, E. (ed) HIV \& AIDS in Africa. London: Blackwell Publishing Ltd: 304-315.

GIFFORD, A.L., LORIG, K., LAURENT, D. \& GONZALEZ, V. 2000. Living well with HIV \& AIDS. London: Boulder Bull Publishing Company.

GOW, J. \& DESMOND, C. 2002. Impacts and interventions. Scottsville: University of Natal Press.

HARRISON, A. 2005. Young people and HIV/AIDS in South Africa: prevalence of infection, risk factors and social context. In: ABDOOL KARIM, S.S. (ed) HIV/AIDS in South Africa. Cape Town: Cambridge University Press: 262-284.

HARRISON, R. \& WISE, C. 2005. Working with young people. London: Sage Publications.

HERBST, A.G. 2002. Life maps as technique in a social group work programme for young adults with HIV/AIDS. Potchefstroom: PU for CHE. (PhD Thesis)

KAMALI, A., SEELEY, J.A., NUNN, A.J., KENGEYA-KAYONDO, J.F., RUBERANTWARI, A. \& MULDER, D.W. 1998. The orphan problem: experience of a SubSaharan Africa rural population in the AIDS epidemic. In: BOR, R. (ed) The family and HIV today. London: Wellington House: 221-232. 
KARTELL, C.G. \& CHABILALL, J.A. 2005. HIV/AIDS in South Africa: a study of the socioeducational development of adolescents orphaned by AIDS in child-headed households. International Journal of Adolescence and Youth, 12(3):213-229.

KASEKE, E. \& GUMBO, P. 2001. The AIDS crisis and orphan care in Zimbabwe. Social Work/Maatskaplike Werk, 37(1):53-58.

MONETTE, D.R., SULLIVAN, T.J. \& DEJONG, C.R. 2008. Applied social research: a tool for the human services. London: Brooks/Cole Cengage Learning.

MYNHARDT, K. 2002. Riglyne vir 'n MIV/VIGS-hulpverleningsprogram aan adolessente ter voorbereiding op ouers se afsterwe. Potchefstroom: PU for CHE. (MA(SW) Dissertation)

NEUMAN, W.L. 2006. Social research methods: qualitative and quantitative approaches. New York: Pearson Education.

NIEBUHR, V.N., HUGHES, J.R. \& POLLARD, R.B. 1998. Parents with human immunodeficiency virus infection: perceptions of their children's emotional needs. In: BOR, R. (ed) The family and HIV today. London: Wellington House: 251-260.

PODILE, M.P. 2004. The knowledge and attitudes of high school learners regarding people living with HIV/AIDS. Potchefstroom: PU for CHE. (MA(SW) Dissertation)

RICHTER, L., MANEGOLD, J. \& PATHER, R. 2004. Family and community interventions for children affected by AIDS. Cape Town: HSRC Publishers.

ROALKVAM, S. 2005. The children left to stand alone. African Journal of AIDS Research, 4(3):211-218.

ROUX, A.A. 2002. Evaluering van 'n groepwerkhulpverleningsprogram met MIVpositief/VIGS-pasiënte. Potchefstroom: PU for CHE. (PhD Thesis)

SAS INSTITUTE INC. 2003. The SAS System for Windows. Release 9.1 TS Level 1 M3 Copyright* by SAS Institute Inc. New York: SAS Institute.

SCHOLTZ, H.E. 1998. Riglyne vir maatskaplike groepwerk met adolessente uit probleemgesinne. Potchefstroom: PU for CHE. (MA(SW) Dissertation)

STRYDOM, H. 2003. HIV/AIDS and South African adolescents: attitudes and information needs. Social Work/Maatskaplike Werk, 39(1):59-72.

STRYDOM, H. 2005a. Sampling and sampling methods. In: DE VOS, A.S. (ed) Research at grass roots: for the social sciences and human service professions. Pretoria: J.L. van Schaik Publishers: 192-204.

STRYDOM, H. 2005b. Ethical aspects of research in the social sciences and human service professions. In: DE VOS, A.S. (ed) Research at grass roots: for the social sciences and human service professions. Pretoria: J.L. van Schaik Publishers: 56-70.

UNAIDS. 2006. Global summary of the AIDS epidemic. [Online] Available: http://data. unaids.org/pub/EpiReport/2006/02-Global_Summary 2006 EpiUpdate eng.pdf. [Accessed: 04/12/2006].

UNGAR, M. 2005. Handbook for working with children and youth: pathways to resilience across cultures and context. California: Sage Publications.

VALDISERRI, R.O. 2003. Dawning answers: how the HIV/AIDS epidemic has helped to strengthen public health. New York: Oxford University Press. 
VAN DER WESTHUIZEN, J.E. 2006. An empowering programme of HIV/AIDS and life skills for adolescents. Potchefstroom: North-West University. (MA(SW) Dissertation)

ISSER, M.J. 2005. Life skills training as HIV/AIDS preventative strategy in secondary schools: evaluation of a large scale implementation process. Journal of Social Aspects of Aids, 2(1):203-214.

WHITESIDE, A. \& SUNTER, C. 2000. AIDS: the challenge for South Africa. Cape Town: Human and Rousseau Tafelberg.

Dr Korita Olivier, Social worker in private practice, Leeudoringstad; Prof Herman Strydom, School of Psychosocial Behavioural Sciences, North-West University, Potchefstroom, South Africa. 